\title{
Inovasi Suplemen Pakan Sakura Blok Plus untuk Meningkatkan Produksi Susu Sapi Perah
}

Amir Husaini Karim Amrullah*, Dadang Suherman ${ }^{2}$ Jarmuji $^{3}$

Program Studi Peternakan, Fakultas Pertanian, Universitas Bengkulu, Jln. W.R. Supratman Kandang Limun, Bengkulu 38371, Indonesia

*amir.hk.amrullah@unib.ac.id

Submisi: 24 Oktober 2018; Penerimaan: 29 November 2019

\begin{abstract}
TKata Kunci:. Abstrak Pemberian suplemen Sakura Blok Plus yang mengandung tepung daun daun katuk; katuk dan kunyit diharapkan mampu meningkatkan produksi susu sapi perah di kelompok ternak; Kelompok Ternak Sumber Mulya. Kegiatan pengabdian dilakukan melalui beberapa tahapan, yakni sosialisasi, pelatihan, demplot, dan uji lapang. Sosialisasi kegiatan suplemen; susu bertujuan untuk memberikan persamaan pemahaman mengenai maksud dan tujuan kegiatan. Pelatihan yang dilakukan memiliki beberapa tujuan, yaitu pengenalan suplemen Sakura Blok Plus, pemahaman manfaat suplemen Sakura Blok Plus bagi ternak sapi perah, bahan-bahan dan peralatan yang digunakan, dan praktik pembuatan. Pembuatan Sakura Blok Plus diawali dengan menimbang bahan-bahan lalu mencampurnya sampai rata. Lalu, panaskan gula merah yang telah dicampur air 20\%. Setelah itu, campurkan bahan-bahan dengan gula merah. Selanjutnya, Sakura Blok Plus dicetak menggunakan alat pengepres. Adapun tahap terakhir adalah pembungkusan Sakura Blok Plus menggunakan plastik wrap. Demplot dan uji lapang dilakukan selama tiga bulan menggunakan tiga ekor ternak sapi perah. Konsumsi hijauan sapi perah yang digunakan dalam demplot berkisar antara 40-45 kg/ekor/hari. Produksi susu sapi perah di Kelompok Ternak Sumber Mulya adalah 10,28 liter/ekor/hari. Penggunaan suplemen Sakura Blok Plus dapat menambah produksi susu 2-3 liter/ekor/hari. Rata-rata produksi susu setelah penggunaan Sakura Blok Plus dapat mencapai 13 liter/ekor/hari.
\end{abstract}

Keywords: katuk leaf; livestock group; milk; suplement
Abstract Giving sakura block plus that contain katuk leaf and turmeric flour are expected to increase the production of milk from dairy cow in Sumber Mulya livestock group. Community service activities are carried out through several stages: socialization, training, demonstration plots, and field tests. Socialization aims to provide an understanding of the purpose and objectives of the activity. The training has several objectives, namely the introduction of sakura block plus supplements, understanding the benefits of sakura block plus supplements for dairy cattle, materials and equipment used, and practices. Making sakura block plus begins with weighing ingredients, then mixed them until blended. Then, heat the brown sugar that has been mixed with $20 \%$ water. After that, mix the ingredients with brown sugar. Next, sakura block plus is pressed by presses tool. The last stage is wrapping it using plastic wrap. The demonstration plot and field test were conducted for three months and using three dairy cattle. The forage consumption of dairy cows used in demonstration plots ranges from 40-45 kg/head/day. Milk production in Sumber Mulya livestock group is 10.28 liters/head/day. The use of sakura blok can increase milk production 2 until 3 liters/head/day. The average milk production after using sakura block plus can reach 13 liters/head/day. 


\section{PENDAHULUAN}

Usaha sapi perah merupakan salah satu sektor usaha peternakan rakyat yang banyak memberi manfaat dalam pemenuhan kebutuhan pangan yang terus meningkat dan penciptaan lapangan kerja. Kondisi geografis, ekologi, dan kesuburan lahan di beberapa wilayah di Indonesia memiliki karakteristik yang cocok untuk usaha sapi perah (Nurtini \& Muzayyanah, 2014). Kabupaten Kepahiang merupakan salah satu wilayah di Provinsi Bengkulu yang cocok untuk pengembangan sapi perah. Secara geografis Kabupaten Kepahiang berada di daerah pegunungan yang bersuhu lingkungan dingin $\left(15-24^{\circ} \mathrm{C}\right)$ dan memiliki kekayaan alam berupa pakan ternak, seperti rumput, limbah pertanian, dan limbah industri pertanian yang melimpah untuk pengembangan sapi perah (BPS, 2017).

Pengembangan sapi perah di Kabupaten Kepahiang dimulai sejak 2008 melalui pembentukan Gabungan Kelompok Tani (Gapoktan) Sumber Mulya di Desa Sukasari, Kecamatan Kabawetan. Permasalahan yang dihadapi peternak sapi perah di Kabupaten Kepahiang adalah rendahnya produksi susu sapi perah dan peternak sapi perah yang belum memiliki kemampuan dan keahlian yang cukup, terutama dalam tata laksana pemberian pakan (ransum) pada sapi perah. Peternak biasanya hanya memberikan pakan (ransum) berupa hijauan dan ampas tahu dalam jumlah terbatas pada ternak sapi perah laktasi.

Suplemen Sakura Blok Plus merupakan modifikasi dari formula UMMB (Urea Mollases Multinutrien Block) dengan menggantikan molasses menggunakan sisa pembuatan gula aren, tepung daun katuk, dan tepung kunyit. Hasil penelitian penggunaan Sakura Blok pada kambing kacang menunjukkan adanya peningkatan ratarata konsumsi bahan kering, bahan organik, konsumsi air minum, pertambahan bobot badan, dan efisiensi pakan (Jarmuji, 2000). Penambahan daun katuk dan tepung kunyit pada ternak perah dilakukan dengan pertimbangan bahwa daun katuk kaya akan zat besi, provitamin A dalam bentuk beta carotine, vitamin $\mathrm{C}$, dan mineral (Santoso dkk., 
2015, 2017). Daun katuk merupakan tanaman obat yang dapat memperlancar produksi air susu, obat demam, dan membersihkan darah kotor (Santoso, 2014). Sakura Blok Plus sebagai suplemen pakan diharapkan dapat berfungsi sebagai karbohidrat yang mudah larut, protein lolos degradasi, dan sebagai sumber glukosa dalam pembentukan bahan baku produksi susu (Jarmuji dkk., 2017).

Kegiatan pengabdian ini bertujuan untuk memberi pemahaman tentang penggunaan suplemen pakan Sakura Blok Plus pada sapi perah sehingga dapat meningkatkan produksi dan kualitas susu sapi perah. Manfaat yang diharapkan dari kegiatan ini adalah anggota Gapoktan Sumber Mulya (a) dapat meningkatkan produksi dan kualitas susu sapi perah yang dipelihara dengan meningkatkan manajemen pakan yang dilakukan serta (b) dapat membagikan ilmu yang didapat kepada anggota kelompok ternak yang lain.

\section{METODE}

Kegiatan pengabdian ini disampaikan melalui beberapa tahapan. Sebelum kegiatan pengabdian dilaksanakan, survei awal dilakukan dengan membagikan kuesioner kepada kelompok sasaran strategis. Hal ini dilakukan untuk melihat tingkat pengetahuan kelompok sasaran strategis perihal gambaran teknologi yang akan diterapkan. Tahapan berikutnya adalah sosialisasi kegiatan, pelatihan, praktik langsung (demplot), dan uji lapang.

\subsection{Sosialisasi Kegiatan Pembuatan Sakura Plus dan Demplot}

Sosialisasi pada peternak sapi perah bertujuan untuk memberikan persamaan pemahaman mengenai maksud dan tujuan kegiatan, prosedur untuk implementasi kegiatan, serta jaminan keberlanjutan dari kegiatan ini. Kegiatan yang disosialisasikan terdiri dari cara pembuatan sakura blok plus dan aplikasi penggunaanya pada ternak sapi 
perah. Sosialisasi dilakukan dengan memberikan penjelasan tentang bahan, tata cara pembuata dan aplikasi pakan suplemen Sakura Blok Plus kepada kelompok sasaran. Pada tahapan ini juga dilakukan tanya jawab.

\subsection{Pelatihan Pembuatan Sakura Blok Plus}

Pelatihan yang diberikan terbagi menjadi beberapa bagian. Pertama yaitu memilih/menyiapkan bahan-bahan Sakura BlokPlus. Kedua adalah cara membuat Sakura Blok Plus. Ketiga adalah cara memberikan Sakura Blok Plus. Keempat yaitu cara menyimpan Sakura Blok Plus. Terakhir adalah cara membuat cetakan blok. Formula Sakura Blok Plus antara lain terdiri dari limbah industri gula merah, dedak, sagu, jagung giling, urea, tsp, garam, mineral catle, top mix, tepung daun katuk, tepung kunyit (Tabel 1).

\section{Tabel 1. Formula Sakura Blok Plus}

\begin{tabular}{clc}
\hline No. & Bahan baku & Formula Sakura Blok Plus (\%) \\
\hline 1. & Limbah industri gula merah & 32 \\
2. & Dedak & 28 \\
3. & Sagu & 15 \\
4. & Jagung giling & 15 \\
5. & Urea & 5 \\
6. & TSP & 1 \\
7. & Garam & 2 \\
8. & Mineral catlle & 1 \\
9. & Top mix & 1 \\
10. & Tepung daun katuk & 2 \\
11. & Tepung kunyit & 2 \\
\hline Jumlah & 100 \\
\hline
\end{tabular}

Sumber: Jarmuji et al. (2017)

Pembuatan Sakura Blok Plus dilakukan dengan menimbang bahan-bahan sesuai dengan formula pada Tabel 1. Setelah itu dilakukan pencampuran bahan-bahan yang sudah ditimbang sampai merata. Tahapan selanjutnya adalah memanaskan gula merah yang telah dicampur air $20 \%$ kemudian mencampurkan bahan-bahan yang sudah ditimbang dengan gula merah tersebut. Tahap berikutnya adalah pencetakan Sakura Blok Plus menggunakan alat pengepres yang dilanjutkan dengan tahapan akhir, yaitu pembungkusan menggunakan plastik wrap. 


\subsection{Demplot dan Uji Lapang Aplikasi Sakura Blok Plus}

Demplot dilakukan dengan mengukur pengaruh pemberian pakan suplemen Sakura Blok Plus terhadap peningkatan produksi susu dan konsumsi hijauan. Demplot dilakukan pada tiga ekor sapi perah pada periode laktasi. Waktu yang dialokasikan untuk demplot kurang lebih selama tiga bulan. Parameter lain yang diukur selama demplot dan uji lapang sebagai berikut.

Produksi susu harian (liter/ekor/hari) yang diukur dengan cara mengukur susu pemerahan pagi dan sore $(\mathrm{kg})$. Pengukuran produksi susu dilakukan tiap hari selama 90 hari. Konsumsi bahan kering hijauan diukur dengan menghitung konsumsi hijauan dikali dengan kadar BK dalam hijauan.

\section{HASIL DAN PEMBAHASAN}

\subsection{Sosialisasi dan Pelatihan Pembuatan Sakura Blok Plus}

Sosialisasi kegiatan bertujuan untuk memberikan persamaan pemahaman mengenai maksud dan tujuan kegiatan. Sebelum dilakukan sosialisasi, tim pengabdian terlebih dahulu berdiskusi dengan Bapak Joko selaku Ketua Kelompok Sumber Mulya mengenai jadwal sosialisasi yang akan dilakukan. Berdasarkan hasil diskusi disepakati bahwa sosialisasi kegiatan dilaksanakan pada 6 Juli 2018, pukul 15.00 WIB. Sosialisasi bertempat di kantor Gapoktan Sumber Mulya. Peserta yang hadir pada saat sosialisasi dan pelatihan berjumlah sepuluh orang peternak sapi perah.

Materi yang disampaikan pada saat sosialisasi dan pelatihan berupa (1) rencana kegiatan pengabdian IPTEKS, (2) pengenalan Sakura Blok Plus pada peternak, (3) manfaat penggunaan Sakura Blok Plus bagi ternak sapi perah, (4) bahan-bahan dan peralatan yang digunakan untuk membuat Sakura Blok Plus, dan (5) praktik cara membuat Sakura Blok Plus. 
Sesi praktik pembuatan Sakura Blok Plus merupakan sesi yang paling menarik. Hal ini disebabkan peternak ikut terlibat aktif dalam praktik pembuatan. Seluruh peternak ikut ambil bagian dalam pembuatan Sakura Blok Plus. Para peternak berharap dapat mempraktikkan langsung di rumah mereka masing-masing. Teknologi alat pengepres Sakura Blok Plus juga menjadi perhatian utama karena alat tersebut menggunakan kayu yang dirangkai. Hal tersebut membuat peternak tertarik untuk mempelajari dan mencoba membuat alat pengepres Sakura Blok Plus.

Berdasarkan hasil sosialisasi diketahui bahwa peternak sapi perah di Kabawetan belum mengenal teknologi pakan Sakura Blok Plus. Peternak memiliki antusias yang tinggi untuk mencoba menggunakan Sakura Blok Plus pada ternak-ternaknya. Hal yang menjadi daya tarik utama bagi peternak untuk menggunakan Sakura Blok Plus adalah kemudahan bahan-bahan, proses pembuatan, dan aplikasinya pada ternak.

\subsection{Demplot dan Uji Lapang Pemberian Sakura Blok Plus}

Aplikasi penggunaan Sakura Blok Plus pada ternak sapi perah diujicobakan pada tiga ekor sapi perah. Aplikasi dilaksanakan selama tiga bulan, yaitu dimulai pada 17 Juli 2018 s.d. 17 Oktober 2018. Sebelum aplikasi, tim pengabdian IPTEKS terlebih dahulu mempersiapkan Sakura Blok Plus yang akan digunakan. Pembuatan Sakura Blok Plus dilakukan sebanyak tiga kali.

Pencatatan produksi susu dan konsumsi pakan harian dilakukan selama tiga bulan aplikasi Sakura Blok Plus pada tiga ekor sapi perah dan sesuai dengan metode yang telah dibuat. Pakan suplemen Sakura Blok Plus diberikan pada masing-masing ternak sebanyak satu buah blok setiap hari.

Berdasarkan hasil pengamatan diketahui bahwa seluruh ternak yang digunakan tidak membutuhkan waktu adaptasi ketika mengonsumsi Sakura Blok Plus. Hal ini disebabkan Sakura Blok Plus mengandung gula merah yang rasanya disukai oleh ternak 
sehingga daya terima ternak terhadap pakan Sakura Blok Plus sangatlah tinggi (Gambar 1)

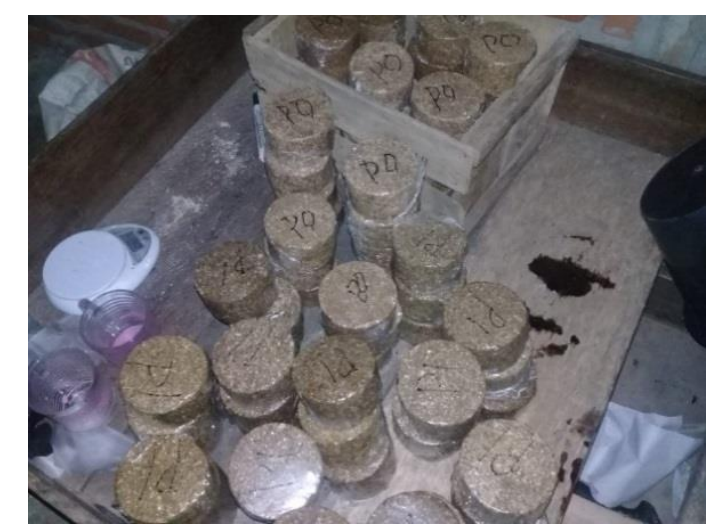

Sumber: Data Primer Diolah (2017)

Gambar 1. Bentuk dan Bungkus Sakura Blok Plus

Proses pengepresan dalam rangkaian pembuatan Sakura Blok Plus menjadikan Sakura Blok Plus berbentuk padat. Bentuk yang padat ini membuat Sakura Blok Plus tidak akan ditumbuhi jamur sehingga dapat disimpan dalam waktu yang lama. Setelah dicetak menggunakan alat pengepres, Sakura Blok Plus kemudian dibungkus menggunakan plastik wrap. Pembungkusan ini juga bertujuan untuk meningkatkan daya lama simpan karena Sakura Blok Plus akan kedap udara dan tidak terpapar langsung dengan udara luar.

\subsection{Konsumsi Hijauan sebagai Pakan dalam Pemeliharaan Sapi Perah}

Hijauan merupakan salah satu pakan utama yang dibutuhkan dalam pemeliharaan sapi perah. Kebutuhan hijauan berkisar $70 \%$ dari total kebutuhan ransum sapi perah setiap harinya. Kualitas hijauan dan jumlah hijauan yang dikonsumsi sapi perah laktasi akan berpengaruh terhadap produksi susu sapi perah. Hijauan yang digunakan di Kelompok Ternak Sumber Mulya terdiri atas rumput gajah, jerami padi, dan jerami jagung. Salah satu hijauan yang digunakan sebagai pakan adalah rumput gajah (Gambar 2). 


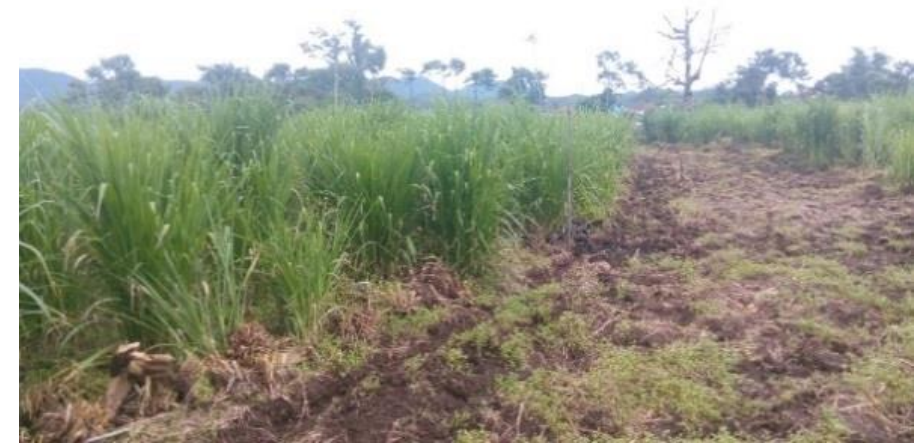

Sumber: Data Primer Diolah (2017)

Gambar 2. Rumput Gajah sebagai Hijauan pakan

Konsumsi hijauan sapi perah yang digunakan berkisar antara 40 sampai 45 kg/ekor/hari. Jumlah konsumsi hijauan masing-masing ternak sapi perah dapat dikatakan cukup. Berdasarkan kisaran bobot badan sapi perah yang dipelihara peternak dengan bobot badan antara 400 sampai $450 \mathrm{~kg}$. Untuk sapi dengan produksi tinggi, pemberian hijauan harus lebih banyak karena sapi perah menghasilkan lemak susu yang didapatkan dari degradasi serat kasar sehingga diperlukan pemberian konsentrat sebagai bahan penguat (Soetarno, 1999).

\subsection{Produksi Susu Sapi Perah}

Proses pemerahan susu sapi perah di Kelompok Ternak Sumber Mulya dilakukan dua kali dalam sehari. Pemerahan pertama dimulai pada pukul 05.00 WIB. Pemerahan berikutnya dimulai pada pukul 16.00 WIB. Pemerahan dilakukan menggunakan mesin pemerah susu. Masing-masing ternak membutuhkan waktu lima menit dalam proses pemerahan, produksi susu sapi perah di Kelompok Ternak Sumber Mulya mencapai 10,28 liter/ekor/hari. Dengan penggunaan suplemen Sakura Blok Plus, produksi susu mengalami penambahan 2 sampai 3 liter/ekor/hari sehingga rata-rata produksi susu setelah penggunaan suplemen pakan Sakura Blok Plus dapat mencapai 13 liter/ekor/hari. Salah satu cara peningkatan produk susu adalah dengan penambahan 
jumlah pemberian sakura blok plus. Hal ini dapat mendorong produksi susu sapi yang lebih tinggi.

\section{KESIMPULAN}

Demplot aplikasi sakura blok plus yang dilakukan selama 3 bulan menunjukkan bahwa suplementasi Sakura Blok Plus berbasis bahan pakan lokal dapat meningkatkan produksi susu sapi perah sebanyak 2 sampai 3 liter/ekor/hari dan konsumsi hijauan 40 sampai 45 kg/ekor/hari. Peternak sapi perah yang tergabung dalam Kelompok Ternak Sumber Mulya telah mengetahui manfaat penggunaan suplemen pakan Sakura Blok Plus dan mampu membuatnya secara mandiri.

\section{DAFTAR PUSTAKA}

BPS. (2017). Monografi Kabupaten Kepahiang. Badan Pusat Statistik Kabupaten Kepahiang.

Jarmuji. (2000). Pengaruh Pemberian Suplementasi Sakura Blok terhadap Bobot Badan Sapi, Konsumsi, Efisiensi Pakan dan Kecernaan pada Kambing Kacang (Skripsi tidak dipublikasikan). Jurusan Peternakan, Fakultas Pertanian, Universitas Bengkulu, Bengkulu.

Jarmuji, U. Santoso, \& B. Brata. (2017). Effect of Oil Palm Frods and Setaria sp as Forages Plus Sakura Block on The Performance and Nutrient Digestibility of Kaur cattle. Pak. J. Nutr. 16(4): 200-206.

Nurtini, S. \& Muzayyanah. M.A.U. (2014). Profil Peternakan Sapi Perah Rakyat. Yogyakarta: UGM Press.

Santoso, U. (2014). Katuk, Tumbuhan Multikhasiat. Bengkulu, Indonesia: Badan Penerbit Fakultas Pertanian, Universitas Bengkulu. 
Santoso, U., Y. Fenita, \& K. Kususiyah. (2015). Effect of Fermented Saoropus Androgynus Leaves on Blood Lipid Fraction and Haemotological Profile in Broiler Chickens. J. Indo. Trop. Anim. Agric. 40(4): 199-207.

Santoso, U., Y. Fenita., \& E. Sulistyowati. (2017). Effect of Saoropus Androgynus Leaf Extract, Fish Oil and Vitamin E on Performance, Egg Quality and Composition in Laying Hens. J. Indo. Trop. Anim. Agric. 42(2): 88—98.

Soetarno, T. (1999). Manajemen Ternak Perah. Yogyakarta: Fakultas Peternakan. Universitas Gadjah Mada. 